How to Cite

Santhia, K., \& Sudiasa, W. (2019). Human rabies epidemiology in Bali, Indonesia. International Journal of Health \& Medical

Sciences, 2(1), 7-16. https://doi.org/10.31295/ijhms.v2n1.77

\title{
Human Rabies Epidemiology in Bali, Indonesia
}

\author{
Ketut Santhia \\ Observer of Zoonotic Disease, Ex. Coordinator of BBVet Denpasar Virology Lab, Directorate General of Livestock \\ and Animal Health, Jakarta \\ Corresponding author email: santhia.adhyputra@yahoo.co.id/sandhytra@yahoo.com
}

\author{
Wayan Sudiasa \\ Bali Provincial of Health Office
}

\begin{abstract}
Epidemiological studies against human rabies have been conducted in Bali using data were obtained from Bali Provincial of Health Office reporting system, and then the data were analyzed by descriptive statistics, the results show domestic dog are main vectors of human transmission while cats, monkeys, and bats do not play an important role in the spread of human rabies in Bali. Similarly, there is no indication of human to human transmission during the incubation period after dog bites and rabies victim treatment in hospital. The frequency and the number of dog bites are likely related to the highly of dogs population density in the residential sector in the region. Dog bite cases showed the highest in 2010 (24.4\%) and are likely to increase following the frequency of cycle dog breeding season occurs in March, and then give birth in July when approaching the peak of the dry season in August, following the mating season in October and breeding season in March, so the next cycle of the breeding season in July and mating season in October. The cases of dog bites resulting in fatalities, during the years 2008 to July 2015 recorded 161 people died, or an average of 20 people per year. A number of fatalities occurred in all districts /municipality, but most occurred in 2010 (82 people), spread over 8 districts/municipality covering 33 subdistricts (57.9\%) and 74 villages (10.3\%). There is an actively infected village that occurred in the districts of Badung, Klungkung, Karangasem, Buleleng, Tabanan, and Denpasar municipality, most occurred in 2009 and 2010 is 7 active villages, respectively. Similarly, the proportion of dog bites cases and the highest death human rabies in 2010 (50.3\%), but the incidence rate highest in 2009 (0.0081\%). Relative risk (RR) victims bitten rabid dogs cause fatalities, 0.0072 times larger than the bitten dog instead of rabies or with a RR ratio in 2008 indicate 2.8 and 2.9 times greater risk of contracting rabies in 2009 and 2010, respectively. Similarly, the RR in 2015 showed 0,0023 times greater risk compared in 2014 or the RR ratio showed 23 times greater risk of contracting rabies compared in 2014. All the sex and age of humans vulnerable to contracting rabies, the proportion of victims of rabies in men $(62.73 \%)$ very significantly higher than women $(37.27 \%)$ and the age range of 3 to 80 years. On the men occurred in the age range of 3 to 80 years and women from 3.5 to 85 years. Distribution of the proportion rabies cases seen highest in the age group of 41 to 50 years (18.01\%), the same age group also occurred in women with a proportion of $21.7 \%$, while that of men is highest in the age group 11 to 20 year with the proportion of $19.8 \%$. It was concluded that rabies is endemic, scattered throughout the districts/municipality in Bali, causing many deaths caused by dog bites rabies infected, however, through the acting post-exposure prophylaxis by treatment and giving VAR rapidly can reduce the human death significantly.
\end{abstract}

Keywords---dogs, epidemiology, humans, rabies, VAR.

\section{Introduction}

The island of Bali is divided into 9 districts/municipality (Badung, Gianyar, Bangli, Klungkung, Karangasem, Buleleng, Jembrana, Tabanan and Denpasar), composed of 57 districts and 716 villages and has an area of 5636,66 $\mathrm{km}^{2}$. The total population of 4,056,27 million inhabitants with a growth rate of $2.6 \%$ per year, consisting of 2,041,97 million and 2,014,3 million male or female sex ratio of 101.7. The population density of about 720 people per $\mathrm{km}^{2}$,

ISSN 2632-9433

Received Jan 20, 2019 / Accepted Jun 18, 2019 / Published Jul 05, 2019 
or an average of 3,73 people (Anon, 2013). The population density / $\mathrm{km}^{2}$ and followed by the dog population density of 250 per $\mathrm{km}^{2}$ in urban areas and 129 per $\mathrm{km}^{2}$ in the countryside with the ratio between dogs and humans 1: 8.27 (Son et al., 2011). The existence of dogs as pets (pet animal) is always close to humans in Bali is believed there is a spiritual relation because the Balineseare really interpreted philosophy Tri Hita Karana, namely the harmonious relationship between humans and the natural environment and other living things, and the relationship with the God Almighty. The relationship will be interrupted when the man himself has ignored the principle of the harmony of the natural world that has lasted for thousands of years. But changing times have transformed the ecology of animal and human behavior, as a result, the victims are humans, animals and the environment itself. When Rabies outbreak in Bali then realized there was a failure to keep and maintain the Bali remained free of rabies. The entry of rabies from infected areas hitherto rabies outbreaks in 24 provinces in Indonesia and is endemic implies a threat to public health in Bali. The indication of the number of dog bite cases popping followed by human victims died. Once the rabies virus known cause is when Bali was also declared as outbreaks of Rabies. Rabies is known as one of the neurotrophic infectious diseases in mammals including humans, causing acute encephalitis that is always followed by death when it appears the clinical symptoms (Swanepoel, 2005). The causative agent of rabies is Lyssavirus genotype 1 (Anna Orlowska et al., 2008), or serotypes 1-challenge virus standard (CVS) (Beran \& Steele, 1994), in the family Rhabdoviridae (Wunner et al., 1995; Nardin-Davis et al., 2008; Kuzmin, 2009), including a family with Lagos bat virus (LBV, genotype 2). Mokola virus (MOKV, genotype 3), Duvenhagevirus (DV, genotype 4), the European Bat Lyssavirus (EBLV1, genotype-5), European bat Lyssavirus (EBLV-2 genotype 6), and Australian Bat Lyssavirus (ABLV, genotype 7), which has a 78 to 93\% amino acid homology (Smith, 1996). Rabies is transmitted through animal bites rabies (Claviland et al., 2006). in Indonesia, including countries in Asia, Africa and South America, the dog is an animal rabies foremost in humans (Goetzee \& Nel, 2007), between 94 to $99 \%$ (Xianjin Wang et al., 2010; Tensin et al., 2010; Pranee Panichabongse, 2001; Swanepoel, 2005; WHO, 2008), whereas the incidence of rabies in the Countries of Europe, America, and Canada rabies virus is transmitted through the bites of wild animals, such as wolves, raccoons, foxes and skunks (Tziana et al., 2010). Almost half the world's population live rabies endemic areas so that the potential of contracting rabies is very high (WHO, 2004). Victims of rabies in Asia and Africa an estimated 55000 to 70000 people each year (Knobel et al., 2005; Dietzschold et al., 2008) and more than 25,000 casualties occurred in India (Sudarshan et al., 2007) In Indonesia, the death toll in the period 6 years (2008 to 2013) recorded 835 people and Bali provinces ranked the after North Sumatra and NTT. The purpose of this study was to determine the epidemiology of human rabies in Bali that the results can be used as a basis for consideration in the policy of prevention, control, and eradication.

\section{Materials and Methods}

Data sources, data dog bite cases and deaths are derived from the data center of Bali Provincial Health Office from May 2008 to July 2015. Most of the data source comes from Districts/municipality hospitals and/or were referred to the General Hospital Center, Sanglah.

Determination of rabies cases. Cases of rabies dog bite determined by history, clinical symptoms, and deaths as well as the examination of samples to confirm conducted at the Biomolecular Laboratory, Faculty of Medical of Udayana University, in addition to data from FAT examination of samples of a dog bite in BBVet Denpasar.

Data analysis. Data were analyzed by descriptive using Microsoft Excel, Graph Pad Software primarily an analysis of the distribution, the proportion of cases, attack rate, incidence rate, relative risk (RR), mean and standard deviation (SD), as well as the confidence interval (CI) bite cases and deaths (Altman, 1991.1998; Setiawan et al., 2018).

\section{Results}

\section{Distribution of Rabies}

The outbreak of rabies in Bali begins after 3 peoples of Ungasan village and a people of the village of Jimbaran, Kuta Selatan subdistrict Sanglah referred to the General Hospital Center, Sanglah from October 12 to November 21, 2008. Those peoples had been treated a day that the majority of suspected rabies symptoms and died on that day too. Fourth peoples have a history of ever bitten by dogs each in July, September and October 2008 and the people were diagnosed with inflammation of the brain (encephalitis). Only when no samples were taken for laboratory 
confirmation. While the dog bite cases continue to spread and there is a resident of Ungasan village, South Kuta subdistrict referred to Sanglah Hospital on November 23, 2008, with a history of dog bites since September 16, 2008, accompanied by symptoms of rabies and died after being treated daily. The sample was taken and tested by RT-PCR were positive rabies virus, but samples of animal rabies newly obtained after dog bite cases against the people at Kedonganan village of Kuta subdistrict on November 26, 2008, the FAT results show positive rabies virus. On the results of the laboratory confirmation, Bali later designated as a rabies outbreak. It is not known with certainty whether the cases of dog bites on a Singapadu village of Sukawati subdistrict in May 2008 who died on May 26, 2010, the first cases indicated as probable cases (Table 1). Majority of $103(64.0 \%)$ cases of rabies in humans is determined based on clinical symptoms and history of dog bites (probable cases), only 58 cases (36.0\%) is determined by laboratory confirmation (confirmed cases).

Table 1

Chronological initial dog bite cases in humans

\begin{tabular}{lll}
\hline Dog bite time & Originally resident & Died \\
\hline Mayi 2008 & Singapadu, Gianyar & May 26, 2010 \\
June 1, 2008 & Sanur, Denpasar & December 26, 2009 \\
June 10, 2008 & Ungasan, Badung & January 16, 2009 \\
July 10, 2008 & Jimbaran, Badung & October 12, 2008 \\
August 2008 & Abang, Karangasem & February 15, 2010 \\
September 2008 & Jimbaran, Badung & April 2, 2009 \\
September 9, 2008 & Ungasan, Badung & November 14, 2008 \\
September 16,2008 & Ungasan, Badung & November 23, 2008 \\
October 2008 & Sanur, Denpasar & Oktober 11, 2009 \\
October 2008 & Ungasan, Badung & January 28, 2009 \\
October 2008 & Ungasan, Badung & March 26, 2009 \\
Oktober 19, 2008 & Ungasan, Badung & November 21, 2008 \\
November 27, 2008 & Pecatu, Badung & March 23, 2009 \\
\hline
\end{tabular}

During the month of December 2008, rabies has caused many deaths in 22 villages (3.1\%) and 13 subdistricts (22.81\%) even in the year 2010 has increased $70.3 \%$, spread in 74 of the 716 villages (10,3\%). But the number and distribution of the victims who died dropped dramatically in 2013 there was only one case was reported in the village of Buyan of Sukasada subdistrict, Buleleng. In the development of the distribution of dog bite cases and deaths have increased in 2014 and until July 2015 spread across 13 villages and 10 subdistricts or increased, 84.6\% and 80.0\%, respectively (Graph 1).

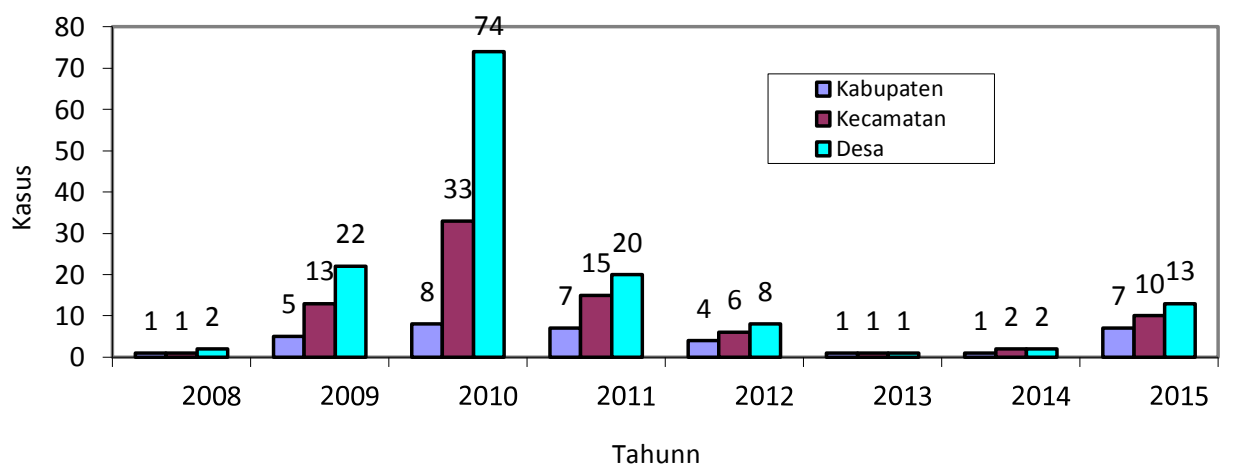

Graph 1. Distribution of human rabies in Bali Province, October 12, 2008, to July 31, 20015

The village of contracting rabies with recurrent cases of deaths occurred in the same village in Denpasar municipality, and in the districts of Badung, Klungkung, Karangasem, Buleleng and Tabanan, most occur in 2009 and 2010, 7 and 8 villages active, respectively (Table 2) 
Table 2

The village of contracting rabies is active in the districts/cities in Bali

\begin{tabular}{|c|c|c|c|c|}
\hline $\begin{array}{l}\text { Districts/ } \\
\text { Municipality }\end{array}$ & 2009 & 2010 & 2011 & 2015 \\
\hline Denpasar & Kesiman & & Kesiman & \\
\hline Badung & $\begin{array}{l}\text { Ungasan } \\
\text { Sanur } \\
\text { Jimbaran }\end{array}$ & $\begin{array}{l}\text { Sanur } \\
\text { Darmasaba } \\
\text { Tuban }\end{array}$ & Darmasaba & Tuban \\
\hline Klungkung & & Banjarankan & & Banjarankan \\
\hline Karangasem & $\begin{array}{l}\text { Kubu } \\
\text { Pidpid }\end{array}$ & Pidpid & & Kubu \\
\hline Buleleng & & $\begin{array}{l}\text { Kaliasem } \\
\text { Gobleg }\end{array}$ & Bon Dalem & $\begin{array}{l}\text { Kaliasem } \\
\text { Gobleg } \\
\text { Bon Dalem }\end{array}$ \\
\hline Tabanan & Timpag & Timpag & & \\
\hline
\end{tabular}

The number of dog bite cases from May 2008 to July 2015 recorded 274,792 cases, an average of 34,349 cases per year (SD.27638,11; 95\% CI 18273.60 to 56251.07) or 95 cases per day. Dog bite cases are highest in 2010 recorded 67,021 cases, with a proportion of $50.93 \%$ of cases the bite, but incidence highest rate in $2009(0.0081 \%)$ and the relative risk (RR) dog bite cases infected with rabies at the beginning of the outbreak in 2008 resulting in deaths, 0.0072 times higher risk than a dog bite cases that occurred in 2009 and 2010 or the ratio of RR in 2008, 2.8 and 2.9 times, respectively greater risk than in 2009 and 2010, RR even years 0.00232015 showed higher risk than in 2014 or 2015 RR ratio is 23 times greater than in 2014 (Table 3).

Table 3

Dog bite cases and deaths, 2008 May - July 31, 2015

\begin{tabular}{|c|c|c|c|c|c|c|}
\hline Years & $\begin{array}{l}\text { Dog } \\
\text { Bite cases }\end{array}$ & Death & $\begin{array}{l}\text { Pro } \\
\text { portion } \\
(\%)\end{array}$ & $\begin{array}{l}\text { Incidence } \\
\text { rate } \\
{[\%]}\end{array}$ & $\begin{array}{l}\text { Relative } \\
\text { Risk } \\
(R R)\end{array}$ & $\begin{array}{l}\text { 95\% Confidence } \\
\text { Interval(CI) }\end{array}$ \\
\hline 2008 & 1.103 & 4 & 2,48 & 0,00012 & 0,0072 & $0,0027-0,0192$ \\
\hline 2009 & 21.805 & 28 & 17,39 & 0,0081 & 0,0026 & $0,0018-.0,0037$ \\
\hline 2010 & 67.021 & 82 & 50,93 & 0,0023 & 0,0025 & $0,0020-.0,0031$ \\
\hline 2011 & 52.798 & 23 & 14,29 & 0,0006 & 0,0009 & $0,0006-0,0013$ \\
\hline 2012 & 55.836 & 8 & 4,97 & 0,00022 & 0,0003 & $0,0001-0,0006$ \\
\hline 2013 & 44.690 & 1 & 0,62 & 0,00002 & 0,0000 & $0,0000-0,0003$ \\
\hline 2014 & 46.877 & 2 & 1,24 & 0,00005 & 0,0001 & $0,0000-0,0003$ \\
\hline 2015 & 11.565 & 13 & 8,07 & 0,0003 & 0,0023 & $0,0013-0,0039$ \\
\hline Total & 274.792 & 161 & 100,0 & & & \\
\hline
\end{tabular}

The number of victims died from rabies since October 2008 until July 31, 2015, as many as 161 people (SD, 26.86, $95 \%$ CI 17.76 to 54.67), at most by 2010 as many as 82 people with a proportion of $50.9 \%$ of cases. The number of casualties caused by the dog bite cases patients rabies in 2008 and 2009, respectively 2 and 14 cases of bites later died in 2010, as well as the victims died in 2009 or 2011 due to dog bite cases that occurred in 2009 and 2010, who died in 2011 as well as deaths in 2013 and 2014 (Graph 2). 


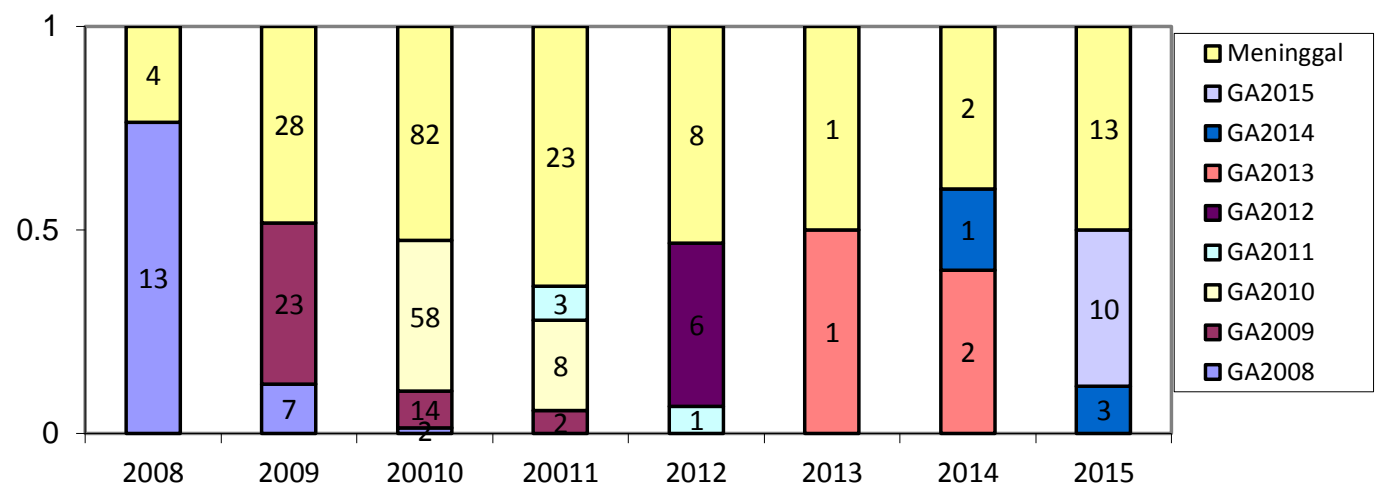

Graph 2. Cases of dog bites and deaths from rabies

Distribution of rabies in each district/municipality in Bali showed the lowest number of cases occurred in the district of Jembrana, 3 cases of deaths or the proportion of $1.86 \%$ (95\% CI 0.39 to 5.58) and the highest in Karangasem district, 41 cases (SD, $12.82,95 \%$ CI 8.86 to 24.56 ), or the proportion of cases $25.47 \%$ (95\% CI 19.34 to 32.74 ) (Table 4).

Table 4

Distribution and proportion of rabies in each district/city in Bali

\begin{tabular}{lllll}
\hline $\begin{array}{l}\text { Districts/ } \\
\text { Municipality }\end{array}$ & Died & Province & Cumulative proportion & $\begin{array}{l}\text { 95\%Confidence } \\
\text { Interval (CI) }\end{array}$ \\
\hline Denpasar & 11 & 6,81 & 6,81 & $3,74-11,94$ \\
Badung & 24 & 14,91 & 21,72 & $10,17-21,28$ \\
Gianyar & 11 & 6,83 & 28,55 & $3,74-11,94$ \\
Bangli & 7 & 4,36 & 32,91 & $1,96-8,87$ \\
Klungkung & 11 & 6,83 & 39,74 & $3,74-11,94$ \\
Karangasem & 41 & 25,47 & 65,21 & $19,34-32,74$ \\
Buleleng & 34 & 21,12 & 86,33 & $15,49-28,09$ \\
Jembrana & 3 & 1,86 & 88,19 & $0,39-5,58$ \\
Tabanan & 19 & 11,80 & 100,0 & $6,55-20,07$ \\
Total & 161 & 100,0 & & \\
\hline
\end{tabular}

By sex, the proportion of the number of rabies cases in the males is $62.73 \%$ (95\% CI 54.77 to 70.21 ) or a ratio of 1.73 times higher than for women (95\% CI 45.23 29,7- ) (Table 4).

Table 5

Distribution and proportion of human rabies based on sex

\begin{tabular}{llllc}
\hline Sex & Rabies cases & $\begin{array}{l}\text { Proportion } \\
\%\end{array}$ & Ratio & $\begin{array}{l}95 \% \text { Cnofidence } \\
\text { Interval (CI) }\end{array}$ \\
\hline Male & 101 & 62,73 & $1,73: 1$ & $54,77-70,21$ \\
Female & 60 & 37,27 & & $29,7-45,23$ \\
Total & 161 & 100 & & \\
\hline
\end{tabular}

In graph 3 , it can be seen that the frequency and distribution of rabies cases by sex show the number of bite cases and the death toll in men is highest ( 82 people) in 2010. 


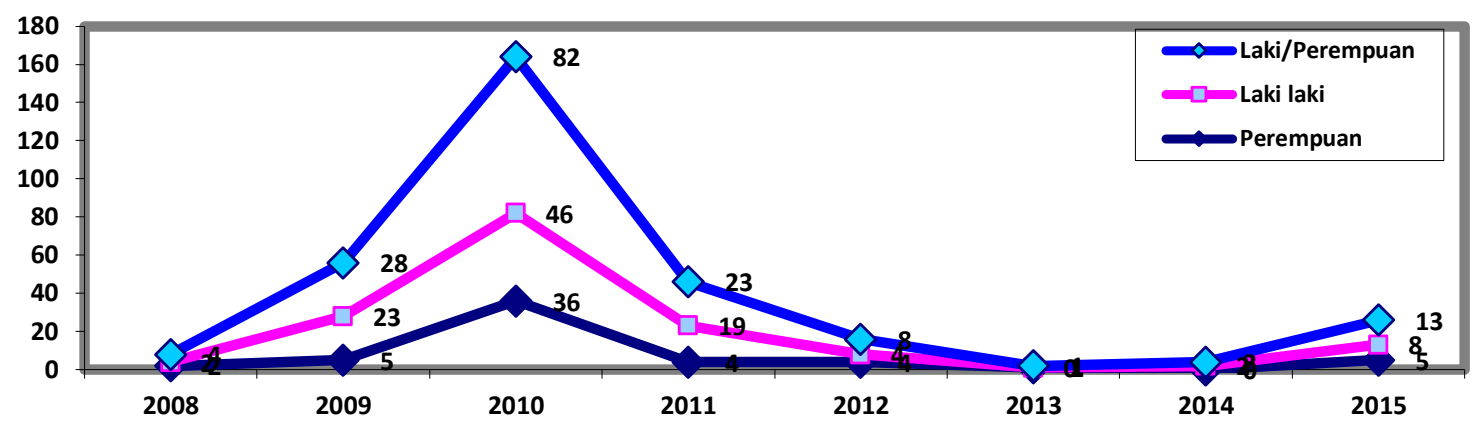

Graph 3. Frequency of rabies cases based on sex differences, 2008- July 2015

Furthermore, based on age group occurred in all age groups from the age range from 3 to 85 years (mean 36.63; SD 20.96; 95\% CI: 18.89 - 23.55), consisting of 101 men with age ranges 3 to 80 years (95\% CI 18.22 - 23.95) and 60 women with ages ranging from 3.3 to 85 years (mean 39.63; SD 21.70; 95\% CI 18.39 - 26, 47). The number of deaths from all age groups was seen most in the age group 41 to 50 years, but by sex, the most were men from the age group 11 to 20 years (20 people), while for women from the age group 41 to 50 (13 people) (Graph 4).

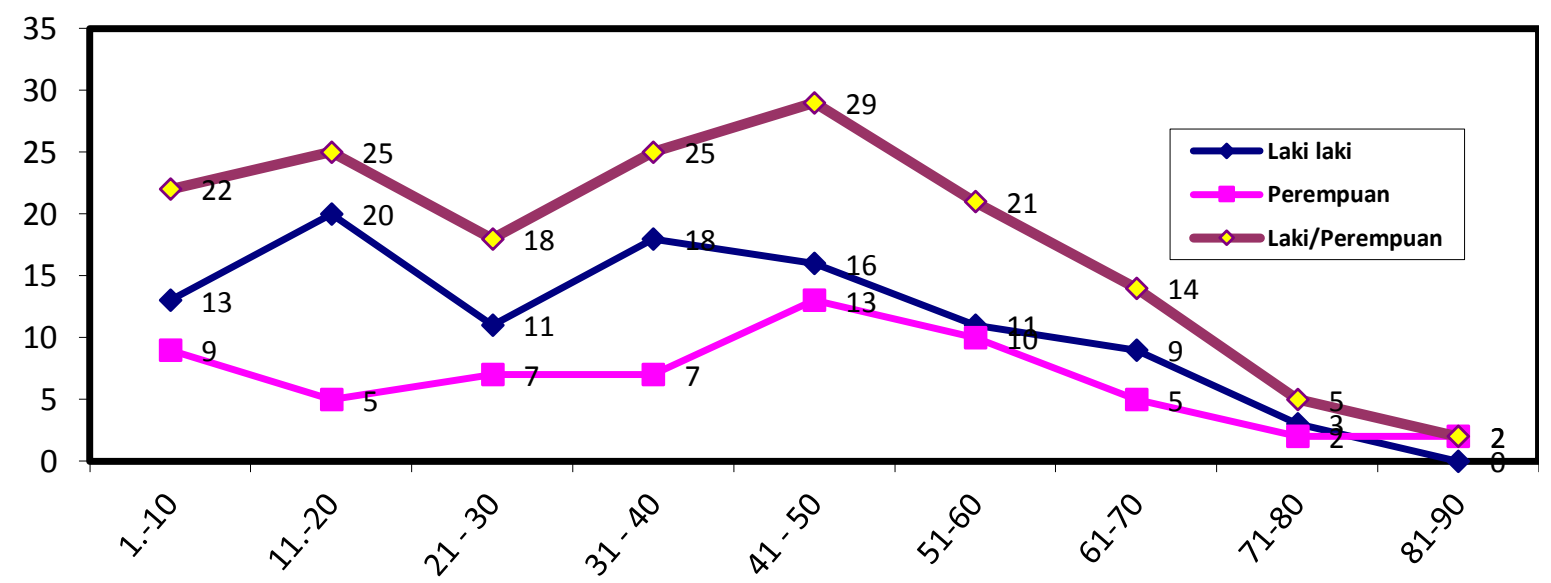

Graph 4. The number of victims dying from rabies by age group and sex

However, based on the distribution of the proportion of rabies cases seen the highest in the age group 41 to 50 years, the same age group occurred highest in women with a proportion of $21.7 \%$ (95\% CI 12.99 - 33.62), while in the male males were highest in the 11 to 20 year age group with a proportion of $19.8 \%$ (95\% CI 13.12-28.69) (Table 6).

Table 6

The proportion of men and women die from rabies by age group

\begin{tabular}{|c|c|c|c|c|c|c|c|}
\hline \multirow{3}{*}{ Age group } & \multirow{3}{*}{ Male } & \multirow{3}{*}{ Female } & \multicolumn{2}{|c|}{ Proportion } & \multirow{3}{*}{$\begin{array}{l}\text { Difference } \\
\text { in } \\
\text { proportion }\end{array}$} & \multirow{2}{*}{\multicolumn{2}{|c|}{$\begin{array}{l}\text { 95\% Confidence Interval } \\
\text { [CI] Proportion }\end{array}$}} \\
\hline & & & \multirow{2}{*}{ Male } & \multirow{2}{*}{ Female } & & & \\
\hline & & & & & & Male & Female \\
\hline $1-10$ & 13 & 9 & 12,9 & 15,0 & 2,1 & $7,54-20,92$ & $7,87-26,47$ \\
\hline $11-20$ & 20 & 5 & 19,8 & 8,3 & 11,5 & $13,12-28,69$ & $3,21-18,47$ \\
\hline $21-30$ & 11 & 7 & 10,9 & 11,7 & 0,8 & $6,03-18,62$ & $5,47-22,48$ \\
\hline $31-40$ & 18 & 7 & 17,8 & 11,7 & 6,1 & $11,49-26,51$ & $5,47-22,48$ \\
\hline $41-50$ & 16 & 13 & 15,8 & 21,7 & 5,9 & $9,89-24,30$ & $12,99-33,62$ \\
\hline $51-60$ & 11 & 10 & 10,9 & 16,7 & 5,8 & $6,03-18,62$ & $9,11-28,23$ \\
\hline $61-70$ & 9 & 5 & 8,9 & 8,3 & 0,6 & $4,57-16,26$ & $3,21-18,47$ \\
\hline
\end{tabular}




\begin{tabular}{llllllll}
$71-80$ & 3 & 2 & 3,0 & 3,3 & 0,3 & $0,65-8,74$ & $0,25-12,03$ \\
$81-90$ & 0 & 2 & 0,0 & 3,3 & 3,3 & $0.0-4,40$ & $0,25-12,06$ \\
Total & 101 & 60 & 100,0 & 100,0 & & & \\
\hline
\end{tabular}

\section{Animal transmitting rabies}

During the rabies outbreak in Bali, there have been bites of wild dogs and home dogs which have been carried out on 274,792 people, causing 161 deaths $(0.06 \%)$ and no reports of positive rabies cases in other animals, such as cats, apes, and bats.

\section{Influence of season}

Based on BMKG predefined, Denpasar, dry season which lasts from April to November with rainfall $<50$ mm and the rainy season months of December to March with rainfall $>50 \mathrm{~mm}$. The increasing cases of dog bites in humans there seems to be the influence of the season. Visible cases of dog bites are likely to increase following cycles of dogs mating and breeding season. The number of victims died after contracting rabies dog bites in the dry and rainy seasons, 98 people $(60.87 \%)$ and 63 or $(39,13 \%)$, respectively in the dry season the highest seen in 2010,57 peoples $(35.4 \%)($ Graph 5).

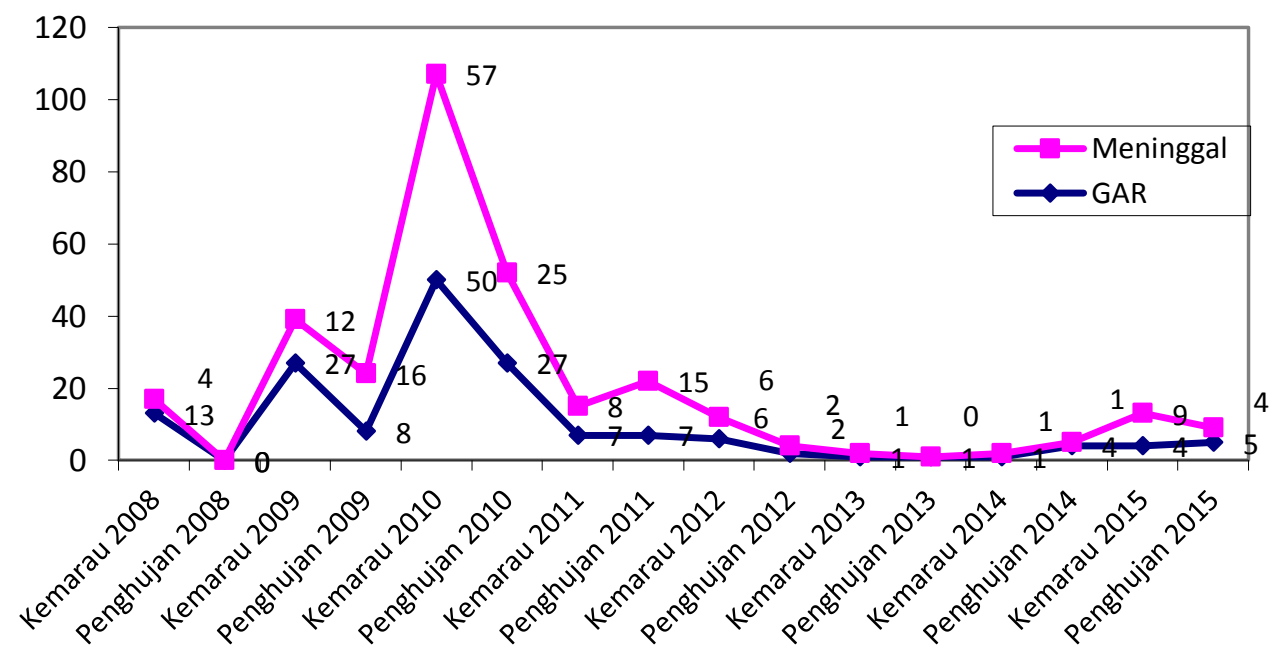

Graph 5. Rabid dog bite cases [GAR] and deaths in the dry season and rainy

\section{Vectors role and mode of transmission of rabies}

There is no indication of the role of mechanical vectors, such as mosquitoes or flies in the transmission of rabies virus in Bali. Modes of transmission of rabies virus only through the bite of a dog and there were no indication of transmission occurs through direct contact, or through the saliva of the victim during hospitalization.

\section{Discussion}

The outbreak of rabies in Bali due to the influx of dogs from infected areas or endemic rabies. This shows the lack of coordination in the supervision of the traffic of animals, especially dogs at the official port, and traditional ports are in the vast expanse of beach that is very long, in addition to the lack of public awareness of the dangers of rabies and even ignorant of the Act or the regulations governing the ban on entering inter Islands dropping animal rabies from infected areas to areas free of rabies. When there is suspicion of rabies arises in handling panic. There are efforts taking action vaccination in animals, but there is no reason to do so because there is no laboratory confirmation, although the diagnosis of encephalitis Hospital set against victims who died with clinical symptoms of rabies and have a history of dog bites. Having no laboratory confirmation of the positive samples of dog rabies and rabies 
outbreaks statement by the Ministry of Agriculture will there be a basis for action vaccination in animals and in humans VAR Award. However, control measures beginning with the elimination of the dog in the case turns implicated the transfer of dogs by their owners out of the area of cases, while there is no rabies vaccination for 6 months from dog bite cases in June and the rabies vaccination was only implemented in December 2008 with coverage vaccination $36.0 \%$ (Son et al., 2009), so that in the period rabies has spread widely and increasingly difficult to control. Rabies in endemic areas with high population density dogs and how the maintenance wilded in a dense residential population can be ascertained cases of dog bites tend to be high. Moreover, dogs infected with rabies virus tends to behave like a terrorist attack and then flee bites suddenly disappears (hit and run) that are difficult to track. Although vaccination has been carried out, if not optimal vaccination coverage of $100 \%$, then the dog is not vaccinated is a risk factor of transmitting rabies virus in humans. Dog in the incubation period appears healthy, but excrete the virus through saliva, especially in the preclinical phase, several days before symptoms appear (Coetzee \& Nel, 2007). There is even a dog infected with rabies virus (strain Ethiopian street rabies virus) at any time can excrete the virus in their saliva during the 305 days after recovery (Fekadu \& Baer, 1980; Fekadu et al., 1981).

The infection rate of rabies virus in the body depends on the location of the bite wound, the amount and speed of uptake of viruses that enter the body are mediated through receptors nicotine acetylcholine (Lents et al., 1982) and affinity virus receptor neurotrophin (Tofferau et al., 1998), after the bite, in addition to the level of replication and expression of glycogen, because this glycogen as the major determinant in the pathogenesis of the virus that facilitates the entry of the virus into the cells quickly ensued trans quickly spread and set the level of viral replication together with other elements. Facts show that the number of dog bite cases spread fast and the number of deaths in all districts/cities in Bali, the most common in Karangasem regency. It is associated with a high population of dogs and the majority of dogs are generally wilded, when a dog bites do not get immediate handling after the bite, but because generally people do not know the dangers of rabies dog bites, but also barriers to access to the Hospital, especially from remote villages or hamlets. Prekuensi highest seen cases occurred in 2010. The death toll in 2010 at the most as a result of the bite cases in 2008 and 2009, the long incubation period until symptoms appear and deaths accumulated in 2010. There were even dog bite cases in May 2008, the clinical symptoms and the victim died two years later.

The length of the incubation period has to do with several factors, such as the dose of the rabies virus in saliva when a bite, the location, and severity of dog bite injuries and post-bite treatment. In its development, the number of fatalities has decreased significantly in 2013 because the public is increasingly conscious to immediately report any cases of bites to health workers so soon get wound care and the provision of post VAR dog bites. The decline in the number of dog bite cases was positive for rabies and the number of fatalities should be the basis of the evaluation of the eradication of rabies, but it made changes to the use of vaccines from local strains that efficacy is not clear. Seen a surge in the number of positive cases of rabies in dogs in 2014 and 2015 exceeded the number of cases in 2010. It seems that the target Bali free of rabies difficult to achieve in a short time, unless there is real action to control the dog population management is kept low through the action of depopulation with sterilization (castration, ovariectomy or injectable hormone) and is limited to the elimination of stray dogs or semi-free-ranging dogs on contracting rabies.

The most effective is the simultaneous action of mass vaccination of the entire population of dogs with a maximum vaccination or $100 \%$ vaccination coverage using a rabies vaccine that has good efficacy. If it can not be ascertained maximum implemented rabies eradication is difficult to achieve. During an outbreak of rabies in Bali, the majority of the victims of dog bites and fatalities are male, as previously reported (Noah et al., 1998; Petersen and Rupprecht, 2010; Pranee Chabhongse, 2001; Ketut Santhia, 2008; Xianjun Wang et al., 2010). All age groups are susceptible to contracting rabies, but most have been infected with rabies in Bali as reported in some countries is the age group 41 to 50 years (Wang Xianjun, 2010; Matsumoto et al., 2013), but based on gender differences showed most of contracting rabies is a male of the age group 11-20 years. The age groups are generally among children up to junior high school students or young workers.

They are relatively more often closer to the dog at home or outside the home tend to be reactive and provocative when dealing with stray dogs or dogs that wilded a house dog. Dog rabies is very aggressive and attacks humans, animals or anything that moves in nearby because of supposed provocation. Rabies cases tend to be high when the season mating dogs or puppies. In case of a bite, the virus directly into the bite wound to reach the peripheral nerve in centripetal subsequently transported to the central nervous system causing acute encephalitis, brain nerve cells undergo demyelination and end with death. Unlike the cat relatively important role in the transmission of human rabies in Bali since cats generally do not bite, but tend to scratch, except that the virus is excreted through saliva is not as much as the dog, and it only takes less than 3 days (Fukadu \& Baer, 1980), Although the virus can be 
transmitted through scratches (Noah et al., 1998), but the number of cases is low at just 3.7\% (Si et al., 2008), even the virus in saliva that pollutes 50 times lower claws (McKay \& Wallis, 2005), If the virus does not immediately get into the victim's body will be inactive or dead by environmental temperature or the sun's ultraviolet rays. The rabies virus is very labile in hot temperatures with a half-life of about 4 hours at $40^{\circ} \mathrm{C}$ and 35 seconds at $60^{\circ} \mathrm{C}$ (Rajesh Bhatia \& Ichhpujain, 1994). Bat and monkey did not play an important role in the transmission of rabies virus in Bali for different ecologies with dogs as pets are very close to humans. Similarly, mechanical vector insects do not transmit rabies because rabies virus infection did not cause viremia such other Rhabdovirus infection.

\section{Acknowledgments}

Further thanks to the Head of the Bali Provincial Health Office, Head of Biomolecular FK, Udayana University, and head of Sanglah Hospital, Hospital Chief and Chief Medical Officer/city for the assistance and cooperation so that the paper can be completed.

\section{References}

Altman, D. G. (1990). Practical statistics for medical research. CRC press.

Altman, D. G. (1998). Confidence intervals for the number needed to treat. Bmj, 317(7168), 1309-1312.

Anon. (2003). BMKG Denpasar, Bali.

Beran, G. W., \& Steele, J. H. (1994). Handbook of zoonoses.[Zowghi E, Trans].

Bhatia, R., \& Ichhpujani, R. L. (1994). Essentials of medical microbiology. Jaypee Broth. Med. Publ..

Campo, E., Swerdlow, S. H., Harris, N. L., Pileri, S., Stein, H., \& Jaffe, E. S. (2011). The 2008 WHO classification of lymphoid neoplasms and beyond: evolving concepts and practical applications. Blood, 117(19), 5019-5032.

Cleaveland, S., Kaare, M., Knobel, D., \& Laurenson, M. K. (2006). Canine vaccination-providing broader benefits for disease control. Veterinary microbiology, 117(1), 43-50. https://doi.org/10.1016/j.vetmic.2006.04.009

Coetzee, P., \& Nel, L. H. (2007). Emerging epidemic dog rabies in coastal South Africa: a molecular epidemiological analysis. Virus research, 126(1-2), 186-195. https://doi.org/10.1016/j.virusres.2007.02.020

Coetzer, J. A. W., Thomson, G. R., \& Tustin, R. C. (1994). Infectious diseases of livestock with special reference to Southern Africa.

Detha, A., Wuri, D. A., \& Santhia, K. (2015). Seroprevalence of Japanese encephalitis virus using competitive enzyme linked immunosorbent assay (C-ELISA) in pigs in East Sumba, Indonesia. Journal of Advanced Veterinary and Animal Research, 2(4), 481-483.

Dietzschold, B., Li, J., Faber, M., \& Schnell, M. (2008). Concepts in the pathogenesis of rabies. https://doi.org/10.2217/17460794.3.5.481

Fekadu, M., \& Baer, G. M. (1980). Recovery from clinical rabies of 2 dogs inoculated with a rabies virus strain from Ethiopia. American journal of veterinary research, 41(10), 1632-1634.

Fekadu, M., Shaddock, J. H., \& Baer, G. M. (1981). Intermittent excretion of rabies virus in the saliva of a dog two and six months after it had recovered from experimental rabies. The American journal of tropical medicine and hygiene, 30(5), 1113-1115.

Knobel, D. L., Cleaveland, S., Coleman, P. G., Fèvre, E. M., Meltzer, M. I., Miranda, M. E. G., ... \& Meslin, F. X. (2005). Re-evaluating the burden of rabies in Africa and Asia. Bulletin of the World health Organization, 83, 360-368.

Kuzmin, I. V., Novella, I. S., Dietzgen, R. G., Padhi, A., \& Rupprecht, C. E. (2009). The rhabdoviruses: biodiversity, phylogenetics, and evolution. Infection, Genetics and Evolution,9(4), 541-553. https://doi.org/10.1016/j.meegid.2009.02.005

Lentz, T. L., Burrage, T. G., Smith, A. L., Crick, J., \& Tignor, G. H. (1982). Is the acetylcholine receptor a rabies virus receptor?. Science, 215(4529), 182-184.

Matsumoto, T., Ahmed, K., Karunanayake, D., Wimalaratne, O., Nanayakkara, S., Perera, D., ... \& Nishizono, A. (2013). Molecular epidemiology of human rabies viruses in Sri Lanka. Infection, Genetics and Evolution, 18, 160-167. https://doi.org/10.1016/j.meegid.2013.05.018

McKay, N., \& Wallis, L. (2005). Rabies: a review of UK management. Emergency Medicine Journal, 22(5), 316321.

Nadin-Davis, S. A., Casey, G. A., \& Wandeler, A. I. (1994). A molecular epidemiological study of rabies virus in central Ontario and western Quebec. Journal of General Virology, 75(10), 2575-2583.

Noah, D. L., Drenzek, C. L., Smith, J. S., Krebs, J. W., Orciari, L., Shaddock, J., ... \& Rupprecht, C. E. (1998). Epidemiology of human rabies in the United States, 1980 to 1996. Annals of internal medicine, 128(11), 922-930. 
Orlowska, A., Smreczak, M. A. R. C. I. N., Trebas, P., \& Zmudzinski, J. F. (2008). Comparison of real-time PCR and heminested RT-PCR methods in the detection of rabies virus infection in bats and terrestrial animals. Bull Vet Inst Pulawy, 52(3), 313-8.

Park, J. H., \& Son, S. H. (2011). Extraction of bitumen with sub-and supercritical water. Korean Journal of Chemical Engineering, 28(2), 455-460.

Petersen, B. W., \& Rupprecht, C. E. (2011). Human rabies epidemiology and diagnosis. In Non-flavivirus encephalitis. IntechOpen.

Setiawan, K., Probandari, A. N., Pamungkasari, E. P., \& Tamtomo, D. G. (2018). Human behaviour in keeping dogs and its relationship to rabies. International Research Journal of Management, IT and Social Sciences, 5(6), 105113. https://doi.org/10.21744/irjmis.v5n6.290

Si, H., Guo, Z. M., Hao, Y. T., Liu, Y. G., Zhang, D. M., Rao, S. Q., \& Lu, J. H. (2008). Rabies trend in China (1990-2007) and post-exposure prophylaxis in the Guangdong province. BMC Infectious Diseases, 8(1), 113.

Smith, J. S. (1996). New aspects of rabies with emphasis on epidemiology, diagnosis, and prevention of the disease in the United States. Clinical Microbiology Reviews, 9(2), 166.

Son, D. T., \& Surowka, P. (2009). Hydrodynamics with triangle anomalies. Physical review letters, $103(19), 191601$.

Sudarshan, M. K., Madhusudana, S. N., Mahendra, B. J., Rao, N. S. N., Narayana, D. A., Rahman, S. A., ... \& Ravikumar, K. (2007). Assessing the burden of human rabies in India: results of a national multi-center epidemiological survey. International Journal of Infectious Diseases, 11(1), 29-35. https://doi.org/10.1016/j.ijid.2005.10.007

Tenzin, B. S., Dhand, N. K., Timsina, N., \& Ward, M. P. (2010). Reemergence of rabies in Chhukha district, Bhutan, 2008. Emerging infectious diseases, 16(12), 1925.

Tuffereau, C., Bénéjean, J., Blondel, D., Kieffer, B., \& Flamand, A. (1998). Low-affinity nerve-growth factor receptor (P75NTR) can serve as a receptor for rabies virus. The EMBO journal, 17(24), 7250-7259.

Wang, X., Ding, S., Li, Z., Wang, L., Kou, Z., Feng, K., .. \& Rupprecht, C. E. (2010). Human rabies epidemiology in Shandong province, China. Jpn J Infect Dis, 63(5), 323-326.

Wang, X., Ding, S., Li, Z., Wang, L., Kou, Z., Feng, K., ... \& Rupprecht, C. E. (2010). Human rabies epidemiology in Shandong province, China. Jpn J Infect Dis, 63(5), 323-326.

Who, E. C. (2004). Appropriate body-mass index for Asian populations and its implications for policy and intervention strategies. Lancet (London, England), 363(9403), 157.

Wunner, W. H., Calisher, C. H., Dietzgen, R. G., Jackson, A. O., Kitajima, E. W., Lafon, M., ... \& Walker, P. J. (1995). Rhabdoviridae. In virus taxonomy. Sixth Report of the International Committee on Taxonomy of Viruses. Springer-Verlag, New York, 275-288. 